2019-03-15

The application of the sustainable livelihood approach to small scale-fisheries: The case of mud crab Scylla serrata in South west India

Apine, E

http://hdl.handle.net/10026.1/14078

10.1016/j.ocecoaman.2018.12.024

Ocean and Coastal Management

Elsevier

All content in PEARL is protected by copyright law. Author manuscripts are made available in accordance with publisher policies. Please cite only the published version using the details provided on the item record or document. In the absence of an open licence (e.g. Creative Commons), permissions for further reuse of content should be sought from the publisher or author. 


\title{
The application of the sustainable livelihood approach to small scale- fisheries: The case of mud crab Scylla serrata in South west India
}

\author{
Elina Apine ${ }^{\mathrm{a}, *}$, Lucy M. Turner ${ }^{\mathrm{a}}$, Lynda D. Rodwell ${ }^{\mathrm{b}}$, Ramachandra Bhatta ${ }^{\mathrm{c}}$ \\ ${ }^{a}$ Marine Biology and Ecology Research Centre, University of Plymouth, Drake Circus, Plymouth, Devon, PL4 8AA, UK \\ ${ }^{\mathrm{b}}$ Marine and Coastal Policy Research Unit, University of Plymouth, Drake Circus, Plymouth, Devon, PL4 8AA, UK \\ ${ }^{\mathrm{c}}$ Department of Fisheries Economics, Karnataka Veterinary Animal and Fisheries Sciences University, College of Fisheries, Mangalore, 575002, India
}

\section{A R T I C L E I N F O}

\section{Keywords:}

Sustainable livelihood approach

Crustacean fisheries

Artisanal fisheries

Fisheries management

Small-scale aquaculture

Vulnerability

\begin{abstract}
A B S T R A C T
The sustainable livelihood approach is an analytical framework that helps identifying the assets that local communities rely on, the risks they are subjected to, organisations and institutions influence their daily lives and the strategies they undertake. This is a valuable approach in small-scale fisheries management as artisanal fisheries are exposed to uncertainty in terms of supply and demand, and fishing activities usually are influenced by social and institutional factors. However, in spite of its usefulness and the fact that this approach has been previously used in projects targeting small-scale fisher communities, it is still not widely applied to small-scale fisheries. In this study we applied the sustainable livelihood approach as an analytical tool to assess the potential of the mud crab Scylla serrata as a sustainable livelihood resource for the southwest Indian states such as Karnataka. As fishers worldwide face continuous pressure from industrial fishing fleets and decreased fish stocks and their productivity, we also identified what could be the potential barriers to small-scale mud crab farming for communities that are already are involved in mud crab fishing. Data were collected and analysed from a semi-structured questionnaire, two focus group discussions and key informant interviews conducted in Uttara Kannada district, Karnataka. The results indicated that though mud crab is perceived as a good source of income in this area, at present it is not recognised as a steady source of income due to the unpredictable fishery catches. Respondents were aware of mud crab farming yet stated the lack of land and financial resources as the main barriers and only the minority expressed any interest in undertaking such activity. The sustainable livelihood approach proved to be a valuable research tool for identifying matters of concern for local communities regarding their source of livelihoods and barriers to small-scale aquaculture.
\end{abstract}

\section{Introduction}

Coastal zones, in particularly in tropical countries, are complex and dynamic areas that are constantly affected by biophysical changes, development plans, tourism, population growth, pollution and many other factors (Campbell et al., 2006). Being at the interface between land and water, coast provides essential livelihoods for agricultural and fisher communities, yet many communities are under pressure due to the land-use change, which often means construction of intensive shrimp aquaculture farms (Gowing et al., 2006). Mangrove forests, rich in biodiversity and acting as nurseries, are particularly affected by this development as disease outbreaks and pollution have been reported regularly in shrimp farms (Páez-Osuna, 2001). Furthermore, adverse influences on the socio-economic conditions of the local fishing communities have been acknowledged (Béné, 2015; Blythe et al., 2015).
Inland fisheries (including estuaries, mangroves and brackish water ponds) mainly comprise small-scale fishers are one of the most vulnerable and poorest groups worldwide (Béné, 2009). Small-scale fishers or, as often referred to, artisanal or traditional fishers, can be characterised by often relying completely on fishing and fishing related activities, using simple gear, having local ecological knowledge that is passed down through generations, being involved in skill-intensive fishing activities close to their settlements and often being highly dependent on middlemen (Kurien, 1996). Fishers worldwide face continuous pressure from industrial fishing fleets and inland fishing communities in developing countries and newly industrialized countries such as India can be the most exposed to natural and economic shocks and disasters thus becoming more marginalised and vulnerable (Béné, 2009). Furthermore, high fishing intensity has led to a significant reduction in marine and coastal fish landings in certain areas (FAO, 2011;

\footnotetext{
* Corresponding author.

E-mail address: elina.apine@plymouth.ac.uk (E. Apine).
} 
Allan et al., 2005). Consequently, the decrease in fish landings together with population growth in India has enhanced the expansion of aquaculture making India the second biggest producer of aquaculture species, including inland and marine finfish species, molluscs, crustaceans and aquatic plants (FAO, 2018), yet mainly limited to brackish water shrimp farming (Nayak, 2017).

Moving in and out of poverty is a dynamic process that can be influenced by various natural, economic, political factors (Baulch and Hoddinott, 2000). Policy interventions to promote intensive aquaculture can negatively influence fisher communities with no access to land and technologies and minimal education (Hossain et al., 2006). Thus, the promotion and implementation of aquaculture should be done together with assessing and finding sustainable livelihood sources for the most vulnerable communities. The sustainable livelihood approach is people-centred approach and has been often used as a practical tool to develop programmes with aims such as poverty reduction or community empowerment, yet it also can be used as set of principles and as an analytical tool (Farrington, 2001). The approach takes into account four dimensions of sustainability - environmental, social, economic and institutional (Ashley and Carney, 1999). Chambers and Conway (1992) define livelihood as 'the capabilities, assets (stores, resources, claims and access) and activities required for means of living' and describe livelihood as sustainable if it 'can cope with and recover from stress and shocks, maintain or enhance its capabilities and assets, and provide sustainable livelihood opportunities for the next generation'. There are several modifications of the sustainable livelihood approach yet all of them are united by common elements - livelihood resources or assets, mediating or transforming processes, livelihood strategies and sustainable livelihood outcomes (Scoones, 1998; Ashley and Carney, 1999; Department for International Development, 1999; Ellis, 2000).

Livelihood assets comprise five types of capital - natural (e.g. land, biological resources), physical (e.g. infrastructure, gear), financial (e.g. incomes, savings, remittances), human (e.g. health and education) and social capital (social ties within community) (Scoones, 1998; Ellis, 2000). Access to these assets however could be enhanced or hindered by institutions and organisations, in addition to being influenced by seasonality, trends and shocks known as the vulnerability context (Ellis, 2000; Allison and Horemans, 2006). Consequently, taking into account the set of assets possessed and the access mediated by social factors and trends, households adopt particular strategies that are flexible and dynamic (Ellis, 2000).

The sustainable livelihood approach is a valuable approach in smallscale fisheries management as artisanal fisheries are exposed to uncertainty in terms of supply and demand, and fishing activities usually are influenced by social and institutional factors (Allison and Ellis, 2001). However, in spite of its usefulness and the fact that this approach has been previously used in projects targeting small-scale fisher communities (e.g. Kébé and Muir, 2008; ECFC, 2005; Kébé et al., 2009), it is still not widely applied to small-scale fisheries (Allison and Ellis, 2001; Allison and Horemans, 2006).

The mud crab (Scylla serrata), also known as the giant mud crab, mangrove crab (Johnson, 2015) or green mud crab (Department of Fisheries, 2013), ${ }^{1}$ can be found throughout the Indo-Pacific region, including the east and the west coasts of India. Due to its relatively large size and delicate meat, it is in growing demand and is one of the economically most important species in coastal regions (Le Vay, 2001). Mud crab habitat is strongly associated with mangrove forest ecosystems and estuaries (Marichamy and Rajapackiam, 2001), it is tolerant to varying salinity and temperature (Ruscoe et al., 2004) and can be cultivated in mangrove incorporated pens without the destruction of the natural mangrove forests. This makes mud crab fishing and farming a prime candidate for investigation as a source of sustainable

\footnotetext{
${ }^{1}$ Hereinafter Scylla serrata will be referred to as mud crab or giant mud crab interchangeably locally in Kannada language known as nukedi.
}

livelihoods in vulnerable coastal regions in India. Traditional farming methods, however, rely on wild animals causing a decrease in the wild population in some areas (Fielder and Allan, 2004). However, recent breakthroughs in commercial $S$. serrata hatchery production of juveniles (Quinitio et al., 2002) if made easily accessible to fisher communities could remove the burden to wild stocks. Despite the fact that inland fisheries are a prime sector of employment and livelihoods in India, there are well acknowledged gaps in data collection of parameters such as fishing effort and per capita yield (Central Statistics Office, 2011). Due to the lack of this significant data, no maximum sustainable yield of Scylla spp. has been estimated in India or other countries.

Fishing and farming of the giant mud crab is a common activity only in some Indian states, mainly on the east coast such as Andhra Pradesh, Tamil Nadu and West Bengal, and the state of Kerala on the west coast (Marichamy and Rajapackiam, 2001; Thampi Samraj et al., 2015). However other states in the west, especially Karnataka, seem to be far from exploiting the economic potential of this species. Thus, the aim of this study is employ the sustainable livelihoods approach to assess the potential of mud crab fishing and farming as a sustainable livelihood resource in south west India, in particular Karnataka. With the help of the sustainable livelihood approach we identify the capital stocks possessed by fishers, their livelihood strategies and the vulnerability context of local fishers.

\section{Materials and methods}

\subsection{Study area}

In terms of fisheries production, India is the seventh and third leading country in marine and inland capture production respectively, and in 2013 it had 9.7 million fishers and 4.2 million fish farmers (FAO, 2015). In 2014-2015, fish production in India was 3.49 million tonnes of marine fish and 6.58 million tonnes of inland fish, and Karnataka contributed with 389822 and 223419 tonnes, respectively (Department of Animal Husbandry, Dairying and Fisheries, 2015). The value of marine exports to international markets reached 5007 million US dollars in 2013-2014, almost a third more than in 2012-2013 (Marine Products Export Development Authority, 2018).

India has $8118 \mathrm{~km}$ long coastline and a total of 7.3 million hectares of inland water bodies (Department of Animal Husbandry, Dairying and Fisheries, 2014). This study was conducted in the Uttara Kannada district of Karnataka state located on the south west coast of India. There are several rivers in Karnataka originating from the Western Ghats mountain range that runs broadly parallel with the south west coast of India. These create a network of estuaries which provide habitat for many commercially important species, e.g. crabs, prawns, bivalves and fin fish. Karnataka itself has a $360 \mathrm{~km}$ long coastline and 8000 ha of brackish water (Government of Karnataka, 2016), yet aquaculture is mainly limited to shrimp farms (Basavakumar et al., 2011; Goswami and Zade, 2015). There are 30713 fishermen families in Karnataka of whom 28533 are considered as traditional fishermen families (fishing is their ancestral occupation), 32037 of fishers are involved in full time fishing and 6657 in part time fishing (Central Marine Fisheries Research Institute, 2010).

Uttara Kannada is a coastal district located north to Karnataka's chief port city Mangalore with agriculture and fishing as the main economic activities (Bhatta and Bhat, 1998). Mangrove ecosystems, to which mud crab habitats are strongly linked, are found within Uttara Kannada in estuarine complexes of the rivers Aghanashini, Sharavati, Gangavali, Kali and Venkatapur (Sulochanan, 2013) with the four former serving as study sites (Fig. 1).

The Aghanashini estuary is rich in biodiversity and is highly productive due to the organic material flow from the Western Ghats and mangrove systems (Subash Chandran et al., 2012). Aghanashini flows through Kumta taluk (administrative division), consisting of 30 villages 


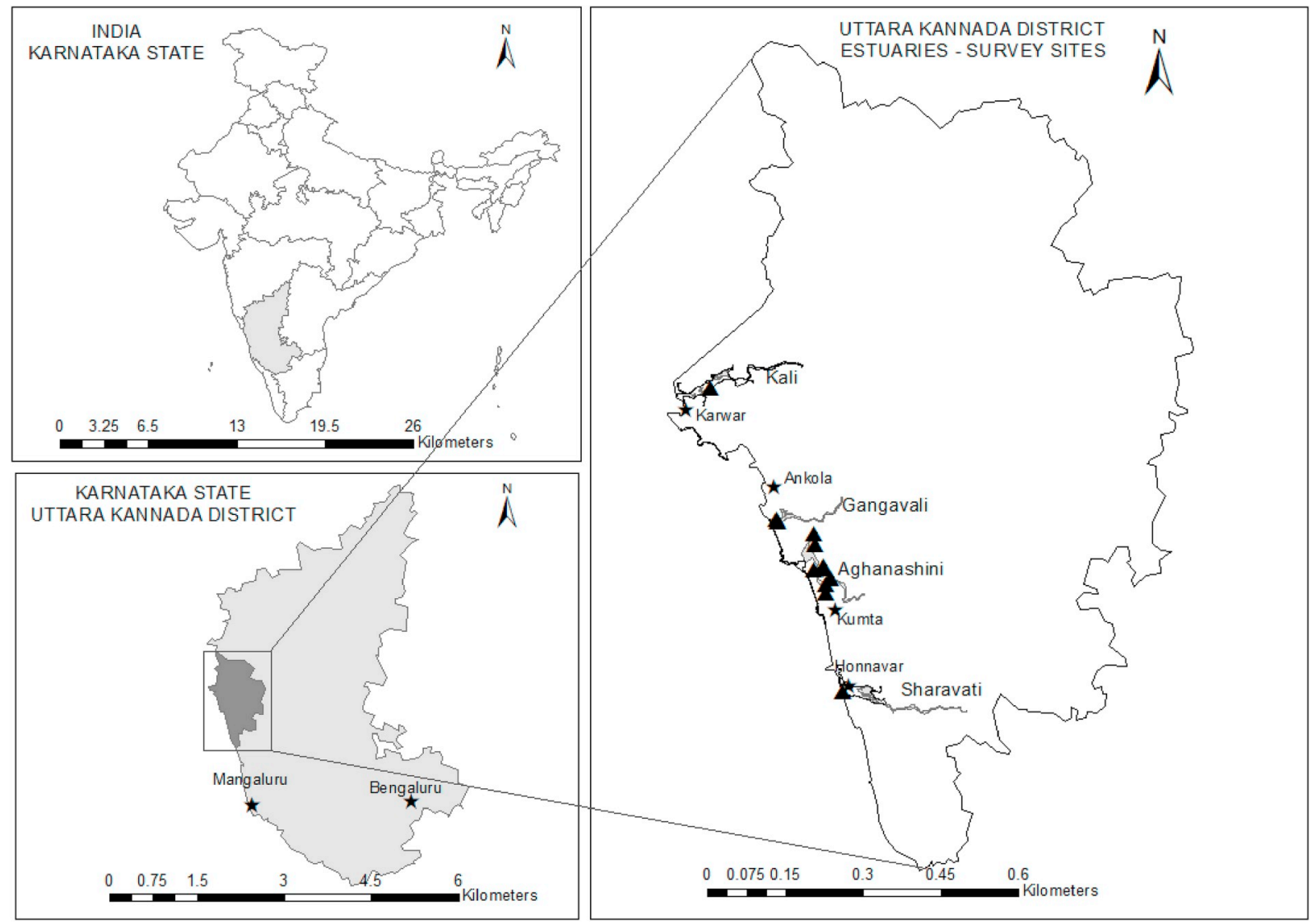

Fig. 1. Study sites in Kali, Gangavali, Aghanashini and Sharavati estuaries indicated with triangles and the closest cities - Karwar, Ankola, Kumta and Honnavar indicated with stars.

with 3269 fishermen families (Central Marine Fisheries Research Institute, 2010). Aquaculture practices in the Aghanashini estuary focus on closed watersheds, called gazani, which are flood-affected lands of farmers pooled on collective farming arrangements (Bhatta and Bhat, 1998). These watersheds are surrounded by embankments built by the state government in the 1970s and have sluice gates that can be opened and closed to control the water flow in and out of the gazani (Bhatta and Bhat, 1998).

The Aghanashini and Gangavali are free-flowing rivers. In comparison, dams have been constructed in the Sharavati and Kali estuaries for hydro-electric power generation. It has been found that two hydroelectric power stations in Sharavati have decreased salinity in the river thus inducing a decline in the fish population (Bhat et al., 2012). Besides the giant mud crab $S$. serrata, two other species of mud crab $S$. olivacea and $S$. tranquebarica can also be found widely in Indian estuarine waters, but due to the relatively low price these fetch, they are mainly sold in local village markets or used for self-consumption. During this study identification of these species was not carried out therefore they will be referred to as red crabs or kempedi in Kannada without specifying the species as $S$. olivacea or $S$. tranquebarica.

\subsection{Data collection}

A structured questionnaire was designed to obtain qualitative and quantitative data on fishing activities, in particular mud crab collection as well as social, economic and environmental factors influencing fishers and their daily activities. The questionnaire was divided into five sections - fishing activities, mud crab collection/fishing, mud crab cultivation, shocks and trends, structures and processes (institutions and trust). Surveys took place in January and February 2018 in Aghanashini $(n=24)$, Gangavali $(n=10)$ and Sharavati $(n=10)$ estuaries (Fig. 1). Respondents were identified by purposive sampling, a sampling strategy that focuses on cases with particular attributes (Aldridge and Levine, 2001), with the help of local interpreters. Surveys were carried out in various areas of these estuaries where mud crab fishing is known to occur. For all individuals fishing was part of their economic activity.

To obtain information from Kali estuary, a focus group discussion based on the questionnaire was organised (FG Kali). In this specific case fishers were willing to answer as a group, therefore the focus group consisted of ten respondents. Fishers answered the questions of the questionnaire as a group with five respondents being more active, while the rest agreed or added short statements. Fishers were also given an opportunity to add any information they thought is important. To be able to compare, one focus group discussion of nine respondents was also conducted in Aghanashani estuary (FG Aghana). In addition, informal semi-structured interviews were conducted with middlemen $(n=6)$ - intermediaries, who purchase crabs from fishers and resell them further. With 69 responses in total, and regular repetition of key information in responses, the study was not expanded further due to the indication that the saturation point had been reached (Saunders et al., 2018). Secondary demographic data of Karnataka were used as complementary contextual data.

\subsection{Data analysis}

The questionnaire was designed to be analysed by applying the sustainable livelihood approach. While the analysis could begin from any of the components of the sustainable livelihood framework and Department for International Development (1999) has suggested the vulnerability context as the initial starting point, we consider livelihood resources as the most suitable starting point. Livelihood assets or 
capitals give people capability to act and should not only be seen as a 'means through which they make a living; they also give meaning to the person's world' (Bebbington, 1999). Entitlement of the capitals may change over time and each of these type of capitals can transform into other types of capital through transforming processes (Department for International Development, 1999). Unlike Bebbington (1999) who recognised produced, human, natural, social and cultural capital assets, current sustainable livelihood approaches acknowledge human, natural, social, financial and physical capitals.

In order to assess capital possessed by fishers and create a capital pentagon (Department for International Development, 1999), we developed criteria for each type of the capital (described in Table 1). We evaluated them on a scale from one point (low) to three points (high) for each respondent's assets and recorded a mean score per estuary presented in the results section. We consider traditional knowledge to be poor if there is a lack of knowledge transfer over generations. Most of the small-scale traditional communities often rely on local ecological knowledge transferred from generation to generation, that gives a significant contribution in natural resource management and conservation programmes (Aswani et al., 2018). Infrastructure was assessed based on whether there are roads and public transport to local market as well as electricity at the village. Sites with acknowledged decrease of mud crab catches due to overfishing or other disturbances were identified as depleted natural resource sites that would limit the quantity and diversity of fishers' catch.

Quantitative and qualitative data were analysed using descriptive statistics and graphical analysis using the Statistical Package for Social Scientists (IBM SPSS Statistics 24) and Microsoft Excel 2016. Chi-square tests of independence were carried out to test for statistically significant differences in how often the mud crabs are caught, the perception of changes in mud crab population, and the willingness to undertake mud crab farming depending on location and the level of education. Nonparametric Kruskal Wallis Tests were used to test if there were statistically significantly differences between each type of capital and the location.

\section{Results}

\subsection{Demographics}

Uttara Kannada has the largest fisherfolk population in Karnataka constituting 16236 families of which $89 \%$ are below the poverty line (USD 1.90 per day) and 48\% do not have any formal education (Central Marine Fisheries Research Institute, 2010). The fishers interviewed in our study were both male (68\%) and female (32\%) of whom $64 \%$ were women who were going fishing themselves, while $36 \%$ answered on behalf of their husbands. Respondents were from Hindu, Muslim and Christian communities with Kannada, Konkani or Urdu as their mother tongues. The majority of fishers interviewed have been fishing or have been involved in fishing related activities, such as fixing nets since childhood (46\%) (Table 2.) The average age of the respondents from the FG Aghana was 27, while for FG Kali it was 38 with a higher average formal education level.

\subsection{Application of the sustainable livelihoods approach}

Based on the questionnaire we identified all elements of the sustainable livelihood framework -livelihood assets, transforming structures and processes, vulnerability context and livelihood strategies and outcomes and modified it according to the conditions of Uttara Kannada (Fig. 2.). The capital pentagon illustrates the level of five types of capital in each of four study sites. We evaluated each type of capital (natural, social, financial, physical and human capital) based on our developed criteria (Table 1) for each respondent and focus groups on the scale from one to three and counted the mean score (Table 3) for each estuary. 
Table 2

Summary of the key demographics and assets (\%) in study sites based on the questionnaire results, excluding focus groups.

\begin{tabular}{|c|c|c|c|}
\hline Variables & $\begin{array}{l}\% \text { in Aghanashini } \\
(\mathrm{n}=24)\end{array}$ & $\begin{array}{l}\% \text { in } \\
\text { Sharavati } \\
(\mathrm{n}=10)\end{array}$ & $\begin{array}{l}\% \text { in Gangavali } \\
(\mathrm{n}=10)\end{array}$ \\
\hline Male & 96 & 20 & 50 \\
\hline Female & 4 & 80 & 50 \\
\hline Age class $18-25$ years & 4 & nil & 10 \\
\hline Age class $26-40$ years & 33 & 20 & 40 \\
\hline Age class $41-65$ years & 46 & 80 & 50 \\
\hline Age class over 66 years & 17 & nil & nil \\
\hline $\begin{array}{l}\text { Fishing/fishing related } \\
\text { activities as the only } \\
\text { occupation }\end{array}$ & 83 & 100 & 100 \\
\hline Involved in sea fishing & 25 & 80 & 80 \\
\hline $\begin{array}{l}\text { Catch mud crabs often but } \\
\text { irregularly }\end{array}$ & 54 & 80 & 30 \\
\hline Catch mud crabs rarely & 42 & 10 & 60 \\
\hline Never catch mud crabs & nil & 10 & 10 \\
\hline $\begin{array}{l}\text { Retain mud crabs for self- } \\
\text { consumption }\end{array}$ & 83 & 70 & 70 \\
\hline \multicolumn{4}{|c|}{ Share from mud crabs contributing to total income } \\
\hline Only for self-consumption & 13 & 10 & nil \\
\hline Up to $10 \%$ & nil & 40 & 80 \\
\hline Up to $25 \%$ & 58 & 40 & 10 \\
\hline $25-50 \%$ & 29 & nil & nil \\
\hline
\end{tabular}

\subsubsection{Livelihood assets possessed by fishes in Uttara Kannada district}

The capital pentagon (Fig. 2.) illustrates the level of five types of capital in each of four study sites. Local communities in Aghanashini, Sharavati and Gangavali estuaries in general had medium and high level of capitals, meaning that the natural resources (mud crabs, fish stocks) are not depleted, majority of fishers have received formal education and are members of fishing societies. Physical capital varied in each site as, for instance, in Sharavati estuary fishers did not own boats but were mainly employees on marine boats or were fishing from the coast. Kali estuary showed the highest levels of each capital as the focus group was a community group that deposited money in bank, shared two boats and considered mud crab farming.

The results demonstrated that all fishers had a relatively high level of human capital consisting of skills, knowledge and abilities (Ellis, 2000) and social capital comprising norms and networks (Woolcock, 1998). To identify human capital, we looked at education level and how it affects decisions on utilising other types of capitals. However, quantification of human capital is not fully possible as traditional or local ecological knowledge would not always be considered, and skills and knowledge are highly variable for each individual (Son, 2012). The majority of fishers based on the survey had primary and middle-school education (up to age 14) (27\% and $23 \%$, respectively) and $23 \%$ had no formal education.

The assessment of social capital was carried out by asking whether fishers are part of any formal fishing society with informal conversations revealing how equal they felt both within and amongst communities. All fishers from Kali, Sharavati and Gangavali estuaries were member of formal fishing societies, while $42 \%$ of fishers from Aghanashini estuary as well as all the respondents of FG Aghana were not members. Fishers who were not involved in any formal fishing societies or groups considered themselves as true estuarine fishers and saw fishing societies oriented towards marine fishers. They hold a position that they would not get any external help as inland fisheries are not considered profitable and therefore could only rely on themselves and their family. Furthermore, respondents of FG Aghana were not members of any fishing society as they reported they do not have time for participating in meetings. Therefore, they were not eligible to obtain any support from a fishing society, and they also felt they were in an unequal position compared to other fishing communities which are members of fishing societies. However, fishers of FG Kali had also established their own 'self-group' with the aim to deposit money at the bank that could be used for petrol and other expenses. They also carried out fishing in pairs as one had to operate the boat, showing a high level of cooperation within the community.

The assessment of financial capital was difficult as fishers would not disclose whether they have savings and how much. Therefore, our assessment is based on observation and information regarding fishing societies. Our analysis shows that due to the 'self-group' fishers from the Kali estuary have the highest level of financial capital while Aghanashini has the lowest. More than two thirds (71\%) stated that mud crab collection is profitable but unstable due to the unpredictable catch. The share from the giant mud crab contributing to the total household income was up to $25 \%$ or even less, up to $10 \%$, for most fishers. Only two respondents reported it to reach up to $50 \%$ of the total income.

The natural capital can be assessed by disclosing land ownership and access to natural resources. The majority of fishers do not possess any land other than their homestead land and would not be able to access additional land, therefore showing low levels of natural capital in general.

The physical capital of fishers was evaluated on the basis of boats and gear possessed. Fishers used a wide variety of nets for all types of fish such as throw nets known as bisu balee, disco nets, gillnets, circular nets, big and smaller nets with various mesh size. Crabs were caught either in these fishing nets or with special nets with mesh size $42 \mathrm{~mm}$ or $66 \mathrm{~mm}$ or with small ring nets with chicken waste bait. Informal conversations with fishers acknowledged that infrastructure to village markets and middlemen is well organised. Almost half of the fishers interviewed for the survey owned a boat. Yet, while each of FG Kali respondents possessed their own non-mechanised boat and one also had an outboard motor; none of the respondents of FG Aghana owned a boat.

\subsubsection{Transforming processes and structures in Uttara Kannada}

Access to the livelihood assets can be enhanced or hindered by organisations and institutions that act as transforming processes and structures. As the main structures we identified fishing societies that were described in previous section due to their influence on social capital, government organisations and middlemen. Based on the informal interviews, government organisations have not intervened significantly in processes, yet middlemen who are purchasing mud crabs from fishers and further resell them to export agencies or hotels. Giant mud crabs were mainly sold to middlemen while red crabs were sold to a local village market. Results show that $55 \%$ of respondents would sell crabs, the majority of which are $S$. serrata to a middleman only, while $9 \%$ would sell $S$. serrata to a middleman and other Scylla crabs in a market. Prices reported by fishers and middlemen reflected varying quality and size of mud crabs (Table 4).

We found that three agents sell the mud crabs further to Chennai, Mumbai, Kolkata, Bangalore or Goa from where they are further sold for export to Singapore, Malaysia and other countries mainly in Southeast Asia. However, besides acknowledged demand from Southeast Asia, there is also demand from hotels in India, particularly in the state of Goa, which is an established local and foreign tourist destination. Two middlemen purchasing crabs from fishers in Aghanashini and Sharavati estuaries were selling the mud crabs to the middleman in Karwar (the closest city) and thus receiving the least profit compared to other middlemen interviewed. The middleman in Karwar owns a shop which serves as a purchase/selling point and he is the only middleman in the city for estuarine fish and crustaceans. He also resells to Chennai, Mumbai or Kolkata for export purposes. Although the quantity of crabs caught by fishers fluctuates daily and seasonally, middlemen recognised that they are able to send relatively stable amounts of giant mud crabs daily by bus for further sale. The average amount sold is approximately $150 \mathrm{~kg}$ per month. This could increase up to $400 \mathrm{~kg}$ in the rainy season. 


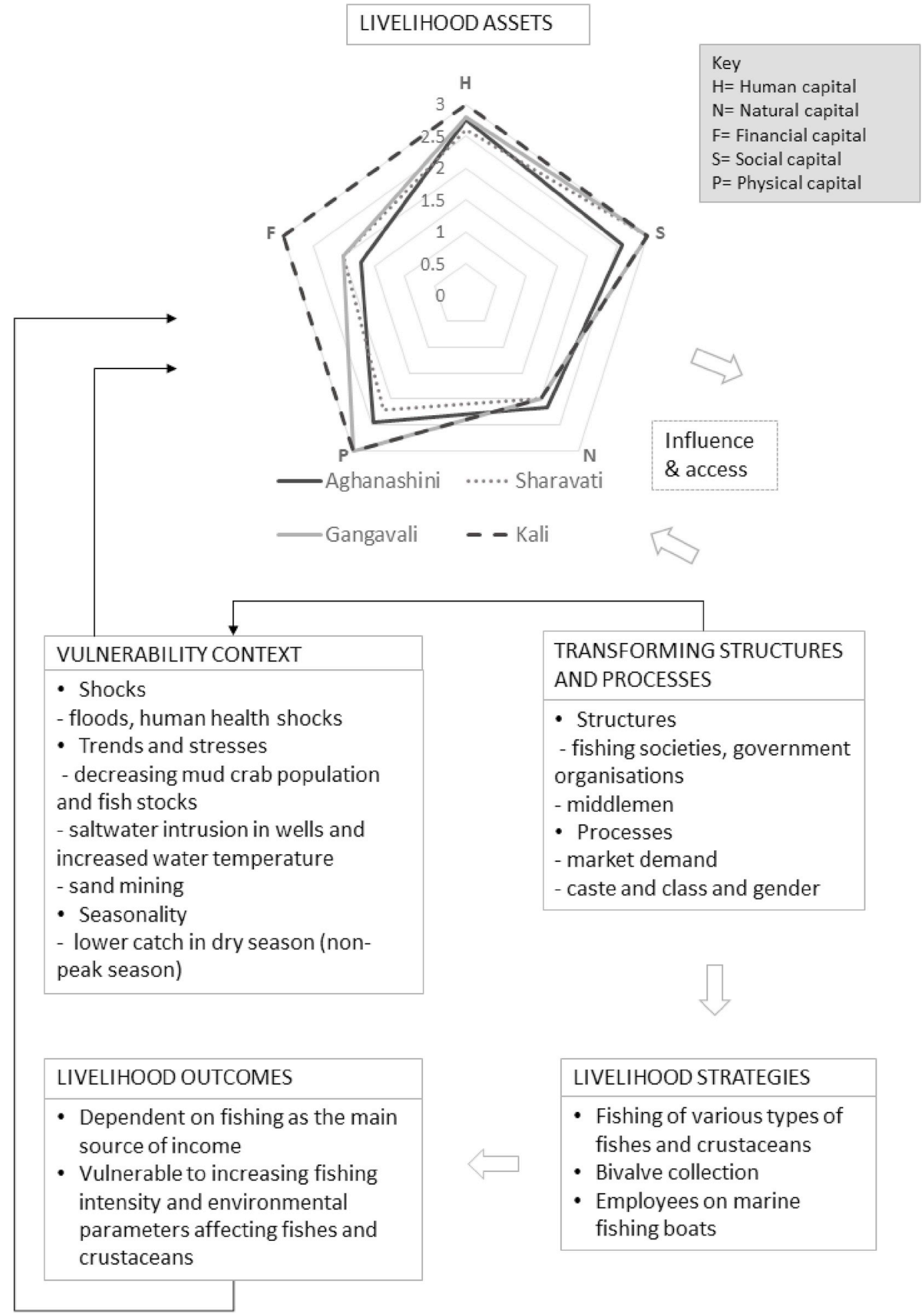

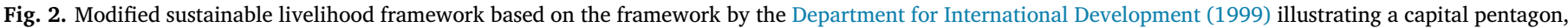

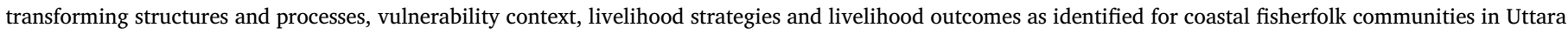
Kannada district.

\subsubsection{Vulnerability context of Uttara Kannada Fisher families}

Various processes, whether they are lasting trends or sudden shocks, can have significant influences on fisher-folk communities. One such trend is the evident decrease in the giant mud crab population which the majority of fishers have noticed over the last years 20 years. Fishers were asked to reflect on what has happened to the mud crab population since they started fishing. Of $71 \%$ who have noticed a decline, $45 \%$ of respondents considered this decline as significant. However, $23 \%$ believed that the population level remains unchanged. There is a significant difference between location and these perceptions $(p=0.042)$. In Gangavali estuary, $70 \%$ of fishers answered that the mud crab population has significantly decreased, while a significant decrease in 
Table 3

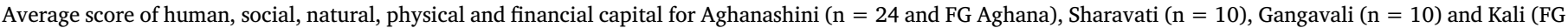

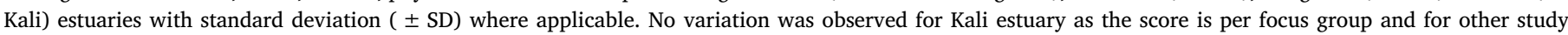

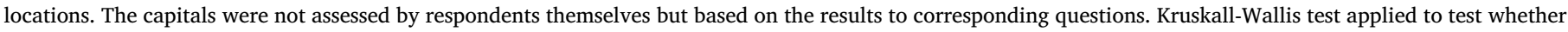
the location affect the level of capitals indicated that there is a statistically significant difference only between location and financial capital.

\begin{tabular}{|c|c|c|c|c|c|}
\hline & Human capital $(\mathrm{p}=0.666)$ & Social capital $(\mathrm{p}=0.012)$ & Natural capital $(\mathrm{p}=0.308)$ & Physical capital $(\mathrm{p}=0.002)$ & Financial capital $(\mathrm{p}=0.018)$ \\
\hline Aghanashini & $2.76 \pm 0.435$ & $2.58 \pm 0.503$ & $2.16 \pm 0.374$ & $2.44 \pm 0.506$ & $1.72 \pm 0.541$ \\
\hline Sharavati & $2.6 \pm 0.516$ & $3 \pm 0.00$ & $2 \pm 0.00$ & $2.2 \pm 0.421$ & $2 \pm 0.00$ \\
\hline Gangavali & $2.8 \pm 0.421$ & $3 \pm 0.00$ & $2 \pm 0.00$ & $3 \pm 0.00$ & $2 \pm 0.00$ \\
\hline Kali & $3 \pm 0.00$ & $3 \pm 0.00$ & $2 \pm 0.00$ & $3 \pm 0.00$ & $3 \pm 0.00$ \\
\hline
\end{tabular}

Aghanashini and Sharavati estuaries was reported by only $33 \%$ and $50 \%$, respectively. However, $42 \%$ of fishers in Aghanashini report a decrease, but claimed it was not extreme.

Although $43 \%$ of respondents could not state any reason for the decline, more than a half had some explanations. Approximately one third of respondents (30\%) thought the decline was due to high fishing intensity. One fisherman recalled that 30 years ago there was a good population of mud crabs in Aghanashini estuary. Another fisherman remembers seeing mud crab burrows that are not common to see anymore. Some fishers also recall that fishers used to catch mud crabs only during the monsoon but now they are collected throughout the year. Others explained the decrease by seasonal changes, tidal changes, oil spills, catching of juveniles and berried female crabs, increasing water temperature, decrease of the river depth and the absence of tiger prawns in rivers.

Fishers were asked to reflect whether various environmental, social and industrial factors have any impact in their daily lives. We found that more than half (55\%) were not aware of any environmental factors and claimed they were not feeling any effect. Only $7 \%$ and $2 \%$ of fishers reported that water pollution and increased water temperature, respectively, significantly negatively influenced their daily life and fishing activities. Yet $11 \%$ of respondents acknowledged mangrove expansion as a positive and significant trend due to their role as nursery habitats. Two thirds of respondents (66\%) claimed that other factors such as sand mining, industrial fishing and fishing intensity were strong influences. Fishing intensity was considered as a significant impact negatively influencing their livelihoods by $39 \%$ of respondents. Sand mining was recognised as a serious problem only by fishers from Aghanashini estuary.

\subsubsection{Livelihood strategies and current outcomes of Uttara Kannada Fisher families}

Fishers in Uttara Kannada are involved in fishing various types of fishes and crustaceans as well as in bivalve collection, specifically in Aghanashini estuary. The giant mud crab is often but irregularly caught by $55 \%$ of total respondents and there was no significant difference between location and frequency of catching mud crabs $(p=0.173)$. Answers regarding patterns and habits of mud crab collection revealed that there is no consistent pattern regarding how often they go fishing per week or per month as it is seasonally dependent. The majority of fishers (61\%) identified the rainy season which lasts from June to September as the peak season for mud crab collection while $11 \%$ recognised the pre-monsoon season, January to May, as the peak season. The amount of crabs caught varied significantly within and between seasons. For instance, one of the fishermen interviewed reported that he had not caught any giant mud crabs for 15 days. By comparison, a different situation is seen with red mud crabs which were reported to be more regularly caught.

Asked whether they know about mud crab farming approaches such as grow-out or fattening systems, $77 \%$ replied positively although $15 \%$ of them considered gazani lands (several hectares) as suitable for mud crab farming and did not think of small ponds or pens (typically $250-2000 \mathrm{~m}^{2}$ ). The vast majority $(71 \%)$ however would not consider undertaking such activity. The key reasons given for not being willing to undertake mud crab farming were lack of land and financial resources with other reasons given including lack of time, knowledge and willingness. Those $9 \%$ who would consider undertaking such an enterprise would be encouraged by initial financial support and if land was made available. Focus group discussions showed that fishers from Kali estuary were aware of mud crab farming techniques and expressed an interest in undertaking such an activity, while fishers from Aghanashini estuary had no knowledge about farming possibilities for mud crabs.

\section{Discussion}

\subsection{Human and social capital and the transforming structures}

Human capital comprises skills, abilities and knowledge in the formal understanding of education and health of labour of the household (Ellis, 2000). Sen (1997) argues that a higher level of human capital also increases human capability of exploiting other types of capital that goes beyond singular understanding of the human capital. Although we did not find a significant difference in responses of the survey between formal education level and a willingness to undertake mud crab farming, focus group discussions suggested that a higher education level might indeed encourage fishers to consider being involved in activities other than capture fishing. The focus group from Kali estuary that was considering mud crab farming if there was financial and educational support, has a higher average education level than the focus group from Aghanashini estuary. Fishers of FG Aghana did not have any knowledge of farming methods and therefore would not consider such activities and did not show any interest in learning. However, respondents of the survey who were interested in mud crab farming had varied education from only one year in education to higher secondary education showing that formal education level does not always indicate people's understanding of economical sustainability, in this case in the form of small-scale aquaculture activities.

The lack of formal education, however, does not mean the lack of knowledge. The majority of these fishers are from families that have been involved in fishing activities over many generations and therefore possess extensive traditional or local ecological knowledge (Berkes

Table 4

Quality classes of giant mud crab with description and average price reported by fishers and middlemen interviewed in 2018.

\begin{tabular}{|c|c|c|c|c|}
\hline Quality class & $1^{\text {st }}$ quality $(\mathrm{XL})$ & $1^{\text {st }}$ quality (big) & $2^{\text {nd }}$ quality & $3^{\text {rd }}$ quality \\
\hline Description & $>800 \mathrm{~g}$ & $550-800 \mathrm{~g}$ intact & $250-350 \mathrm{~g}$ intact or newly moulted ('water') crabs & any size with physical damage such as lost limb \\
\hline Average price (Indian Rupees) & $1000-1200 \mathrm{R} / \mathrm{kg}$ & $300-500 \mathrm{R} / \mathrm{kg}$ & $250-300 \mathrm{R} / \mathrm{kg}$ & $300 \mathrm{R} / \mathrm{kg}$ \\
\hline
\end{tabular}


et al., 2010). One of the fisherwoman who had no formal education said the she would not need any training as she has been going fishing since she was a child and knows every detail she should. In this way she also questioned the usefulness of the training programmes. Traditional knowledge should therefore be taken into account in training programmes as otherwise such programmes might be seen to be undermining fishers' knowledge and not received positively by the communities.

Social capital consists of norms and networks (Woolcock, 1998) and is strongly linked to transforming structures such as community groups. It can be seen as both a product of the transforming structures and processes and the cause of them (Department for International Development, 1999). Social capital does not consist only of formal groups but also of networks based on shared interests and trust, and in a similar way to human capital, is not homogenous (Putnam, 2001).

The fishers who are involved in formal fishing societies would get financial support in case of emergency or death in the family and receive nets and life vests. Yet fishers from Sharavati estuary mentioned that membership of a fishing society does not mean that all of its members would obtain goods, such as gear, equally. Social capital is not always in favour to the people (Putnam, 2001). Besides the benefits of social capital in the form of help from relatives or the extended community, there are also costs related to social capital, especially in the case of strong bonds within certain communities excluding others (Woolcock and Narayan, 2000).

The self-group established by the focus group from Kali estuary indirectly proposed that they are more aware of how significant social capital could be an advantage for their livelihoods. This therefore leads us back to the idea that human capital proves to be important not only in an economic context, meaning that higher education level would increase the chances of receiving a higher income but also increased social development (Sen, 1997).

Although structures that mediate social capital were ambiguously appraised by fishers, community groups for mud crab farming could be the key structure for mud crab to become a sustainable livelihood resource in Uttara Kannada, as most of the fishers see the lack of land and financial resources as the major obstacles. By establishing community groups similar to the self-group of Kali estuary, fishers would likely enhance their livelihoods, strengthen social capital and increase their competitiveness in the market. Mirera et al. (2014) in their study on community organised groups in Kenya found that members of these groups acknowledged that mud crab farming in addition to food supply and direct income also provides employment opportunities and promotes mangrove conservation and restoration. Nevertheless, there were complications with local authorities regarding the use of land and mangroves and also unfair price competition of the crabs due to the lack of policies controlling the market (Mirera et al., 2014). This therefore suggests that if small-scale mud crab farming would be promoted and implemented by the help of governmental or non-governmental organisations in south west India, policies and clear guidelines should be developed regarding land and mangrove use.

\subsection{Natural, physical and financial capital and the transforming structures}

Small-scale fisherfolk communities as well as other communities that obtain most of their livelihoods from resource-based activities are highly dependent on natural capital such as biological resources. Yet, natural capital is not static, fishers recognised a decrease in stocks of fish and crustaceans over their time of fishing. There are no restrictions on the catch size, time and place for fishing in the study sites. Such a phenomenon has also been observed in Chilika lagoon in Odisha state, India by Nayak (2017) where respondents recognised that the high fishing intensity forces fishers to take any size, the perception being that otherwise fish or crustaceans will be caught by somebody else; a risk that cannot be taken in an area with a very low average income.

Another type of natural capital, particularly important for mud crab farming is land. As previously discussed, lack of access to land is the main reason reported as to why fishers are not willing or would not be able to undertake mud crab aquaculture. The data of the National Sample Survey Organisation of India shows that in 2003-2004 in Karnataka $40 \%$ of households did not own any other land other than their homestead (Rawal, 2008). Land ownership in India is highly complex and while land reforms, with the aim of distributing land to the poor and landless have been implemented over the years, there is still significant inequality, especially regarding scheduled castes and scheduled tribes (Bakshi, 2008). Scheduled castes and scheduled tribes (SC/ST) are the lowest castes and tribes that have been historically marginalised (Besley et al., 2016), yet the Government of India has developed legislation and schemes to empower SC/ST (Ministry of Social Justice and Empowerment, 2017). While fishers are not affiliated to any particular caste due to their occupation, most of the fishers belong to the other backward caste (OBC) that is described as economically and socially vulnerable (Chauhan, 2008). Despite the fact that caste affiliation was not identified during the survey, informal conversations and observations suggest that fishers have poor access to land. Mud crab farming could be carried out in mangrove incorporated ponds, yet being a common resource, such a setting might not be the most suitable, unless strong community groups with a high level of trust are established.

In order to be able to obtain education, receive healthcare and sell their catch, basic infrastructure in the form of transportation, communications, safe shelters, adequate water supply and sanitation and energy are needed, e.g. physical capital (Department for International Development, 1999). According to the Marine Fisheries Census 2010 (Central Marine Fisheries Research Institute, 2010) 85 of 86 fishing villages in Uttara Kannada are electrified and 84 have mobile phone coverage, and observations confirmed that there is good basic infrastructure at the study sites. Physical or built capital is a proxy for development in rural areas, as roads, sanitation, water and energy supply attracts businesses and tourism (World Bank, 2012; Mikulcak et al., 2015).

While physical capital possessed by fishers in study sites is relatively high, a different picture is revealed for financial capital. It is the most versatile capital but at the same time commonly the least accessible to poor communities (Department for International Development, 1999). While the aim of this study was not to obtain quantitative economic data on income, savings and costs, we found that the majority of fishers are highly dependent on the income from fishing and do not have any savings or other source of income. On the contrary, when compared to agricultural communities that possess livestock which can be perceived as a store of wealth (Ellis, 2000), fisherfolk communities usually do not possess any such assets. Sen and Homechaudhuri (2017) found that in the Indian Sundarbans mud crab fishers heavily rely on credit known as dadon, a system given by middlemen which has a variable interest rate depending on demand. However, we did not find such a custom to be present in Uttara Kannada.

One of the critiques towards sustainable livelihood approach is that there are no clear guidelines how the capital assets should be measured - whether all of the possible assets for each of the capital has to be included in the analysis or only some of them (Morse et al., 2009). Particularly difficult is to assess land ownership as it tends to be very complex and fragmented. Another critique Morse et al. (2009) identifies is the trust among researchers/development workers and respondents. Fishers interviewed in this study were not willing to disclose the information about their income, therefore it is acknowledged that if respondents withheld information, assets may have been underestimated.

The perception of mud crab by local fishers as profitable indicates that any implementation of sustainable mud crab fishing practices and small-scale farming systems could significantly improve their livelihoods and financial capital. Socio-economic studies in Bangladesh and India under different farming systems (e.g. Ferdoushi and Guo, 2010; Jahan and Islam, 2016; Sen and Homechaudhuri, 2017) have shown 
that small-scale aquaculture systems have proven to be a lucrative activity which also have the potential to contribute to the wider economic context (Sathiadhas and Najmudeen, 2004).

\subsection{Vulnerability context}

Vulnerability is the susceptibility to be harmed (Adger, 2006), and is also strongly linked to the concept of resilience, being the ability to recover from stresses and shocks (Scoones, 1998; Adger, 2006). The vulnerability context consists of trends and shocks including especially those related to seasonality (e.g. monsoon and weather conditions). Despite the fact that artisanal fishers are constantly subjected to seasonality, they often have low resilience towards it (Allison and Ellis, 2001). We found that fishers perceive mud crab collection as an unstable activity because of the high variability in catch from day to day thus suggesting that resource trends are unpredictable.

Fishers could possibly face changes to trends in market prices, although at the moment due to the high demand of mud crab in both the national and international market, prices for mud crabs are stable and only fluctuate slightly according to the price willing to be paid by middlemen. Yet, another important trend that has influence on fishers, is the increasing population in India, and especially the impact of this on coastal areas (Neumann et al., 2015). Respondents have already noticed the effects of this trend in the appearance of increased fishing intensity. Thus, fishers are going to need to adapt to this trend and establish new livelihood strategies. Similar to trends, there are also other stresses that are small and regular disturbances, such as occurrences closely related to climate change, for instance increased water temperature and saltwater intrusion into wells due to sea level rise, which have the potential for long-term impact. We found that sand mining in the Aghanashini estuary has significantly influenced fishers' livelihoods as it destroys bivalve stocks, while fishers reported that it does not have a direct impact on mud crabs. However, studies have revealed that sand mining negatively affects crustacean and fish populations due to removal of juveniles (e.g. Sheeba, 2009; Jonah et al., 2015). Although previously sand mining has been considered an extreme, but irregular event, it is now clear that it should be perceived as a regular stress towards which adaptive actions should be established.

Fishers in Uttara Kannada are also influenced by seasonality. There are distinct seasons in south west India that dictate the life and work of fishers, and cause changes in the availability of fishes and crustaceans. The peak season for mud crabs varies geographically (Kathirvel and Srinivasagam, 1992), but according to a previous study carried out in Karwar, Uttara Kannada district, there are two peaks in the breeding of Scylla serrata, one between December-March and another in September-November (Prasad and Neelakantan, 1989). Seasonality itself is predictable and does not impose a threat, however in combination with climate change it could have a negative effect on the inland fisheries sector (Das et al., 2013).

Compared to the previous disturbances, shocks are unpredictable short-term occurrences with immediate impact (Scoones, 1998). Although fishers did not mention any recent shocks that had an impact on their livelihoods, both natural and human health disasters can take place at any time and if communities are structurally vulnerable, with high sensitivity and low resilience, they can suffer (Allison and Ellis, 2001). We interviewed a woman who had to take over fishing from her husband as he had serious health problems. As she had been involved in fishing activities since her childhood she could easily adapt to the new situation where she is fully responsible for her household's livelihood. However, for other families such a shock could have resulted in the household having no income and sliding into poverty.

\subsection{Livelihood strategies and outcomes}

Livelihood strategies are influenced by the external conditions and they can vary highly between different communities. Even for the same household, livelihood strategies can vary depending on external shocks and stresses (Ellis, 2000). Scoones (1998) identifies three types of livelihood strategies - intensification or extensification (mainly regarding agriculture), diversification and migration. For fishing communities in Uttara Kannada intensification is not possible as the fishing intensity is already arguably too high as fishers report decreases in the mud crab population. While there are no official quantitative data available on changes in the mud crab population in India, the decline has been acknowledged by Rajiv Ghandi Centre for Aquaculture, naming indiscriminate overexploitation (e.g. catching of juveniles, berried female crabs) as the main reason (Thampi Samraj et al., 2015). Compared to Western Australia, where strong regulations are in place for commercial and recreational fishery on the minimum size (150 carapace width for S. serrata) and prohibition on taking berried females and undersized crabs, and limiting the number of pots used (Department of Fisheries, 2018), no such regulations are present in India. However, extensification in the areas fished and species caught could be a strategy for some households that have been focusing on catching only particular species to date.

Allison and Ellis (2001) argue that diversification and high mobility is common among fishing communities especially in low-income countries, however this was not recorded to be the case in our survey sites in Uttara Kannada district. Only one respondent has migrated and worked in another state, whereas all other respondents have only lived in the area they grew up in. We found that the majority of fishers are highly dependent on fishing and it would be their only source of livelihood. However, they would not focus on only one type of fishing but would catch various types of fishes and crustaceans and women would collect bivalves. Only respondents from agricultural communities would harvest crops. Some of the fishers would work as employees on marine fishing boats. However, we suggest that implementation of small-scale mud crab farming systems would be a livelihood diversification that could have a positive effect on fishers' livelihoods. Aquaculture activities also can provide more stable income compared to capture fishing. Counter to Allison and Ellis (2001) who state that for many artisanal fisherfolk families fishing is 'an opportunistic endeavour', we found that fishing for these communities is part of their identity. They would not leave fishing for more profitable activities unless absolutely necessary as has also been observed in the state of Odisha, India by Nayak (2017).

\subsection{Institutional context and environmental sustainability}

Sustainability is a widely accepted, yet continually discussed concept with various interpretations. The general understanding of sustainability can be referred to as economist's definition: 'sustained economic development, without compromising the existing resources for future generations' (Gatto, 1995). Yet, besides economic sustainability, there are two more acknowledged dimensions or pillars of equal importance environmental and social sustainability (Purvis et al., 2018). However, besides these 'three pillars', institutional (Spangenberg, 2002), cultural (Soini and Birkeland, 2014) and technical sustainability (Hill and Bowen, 1997) and even more fragmented dimensions (Vincenzi et al., 2018) have been considered. Whether referred to as institutional sustainability or institutional context, organisations and institutions play fundamental role in growth and development (Acemoglu and Robinson, 2008).

The fishers, mud crabs, estuarine and coastal fisheries and governing organisations and rules are the main subsystems of a complex socio-ecological system that, while being relatively independent, interact to produce outcomes (Ostrom, 2007; McGinnis and Ostrom, 2014). Although each of these units are equally important, governance systems (institutional context) can influence the interaction between other subsystems and enhance or hinder development. Institutional context is also important for assessing the capital assets in the context of vulnerability as some of the shocks and trends can be mitigated by the 
already established institutions and organisations (Morse et al., 2009). In this case study local communities that fish or farm mud crabs can be affected by variables such as government organisations, non-government organisations, middlemen, local village markets, export agencies, hotels, land use rights, operational rules and sanctions. There are several fisheries and aquaculture related government and non-government organisations in India that are active actors in training and promoting certain species, however, based on informal conversations such programmes in Uttara Kannada are not common, yet could take place in the near future. Middlemen, export agencies, hotels and village markets are the units that regulate and reflect the demand of mud crabs. Sen and Homechaudhuri (2017) identified middlemen as 'conservation agents' that could be targeted to implement sustainable fishing practices fishers trust them, they possess traditional knowledge and also are aware of demand and have connections with export agencies or hotels and restaurants. Furthermore, although we did not find the evidence of loan system provided middlemen in Uttara Kannada, such practice could be in place as small-scale fishers have been acknowledged to financially depend on middlemen (Kurien, 1996). In addition, rules and regulations are weak in Uttara Kannada, indicating that it is an area that should be improved. However, any regulations should be introduced carefully taking into account informal cultural institutions and acknowledging that any government interventions can be received with suspicion by small-scale fishers (Jentoft and Chuenpagdee, 2015).

Environmental sustainability can be assessed using various assessment approaches (Little et al., 2016). In regards to fisheries, we consider stock assessment and maximum sustainable yield as a relevant approaches that can reveal how environmentally sustainable is the fishery of a particular species. While there is no country- or state-level stock assessment of mud crabs on country-level in Indo-Pacific region, some regional studies have been carried out showing data on yield and catch per unit effort (CPUE). This could serve as an indirect measure of the abundance of mud crabs. Sen and Homechaudhuri (2017) in their study in Indian Sundarbans found decreased CPUE from March to June and increased CPUE from July up to January of $S$. serrata. Study in the Philippines by Lebata et al. (2009) showed that monthly yield could be increased by $46 \%$ by releasing hatchery-reared mud crabs and gaining yield of $5.54 \mathrm{~kg} \mathrm{ha}^{-1} \mathrm{yr}^{-1}$. Yet, other studies in the Philippines have shown yield of $65.4 \mathrm{~kg} \mathrm{ha}^{-1} \mathrm{yr}^{-1}$ (Walton et al., 2006) and $4.1 \mathrm{~kg} \mathrm{ha}^{-1}$ $\mathrm{yr}^{-1}$ (Lebata et al., 2007) and similar trend of CPUE increasing in certain periods but not the same months as in India due to possible difference in breeding season. Although this data set is limited, as no rapid decline has been seen in CPUE, it indicates that mud crab fishing can be seen as environmentally sustainable. Yet, stock enhancement is beneficial and taking into account increasing human population and thus consequent demand, small-scale aquaculture should be considered as alternative providing steady source of income.

\section{Conclusion}

The sustainable livelihood approach is a useful analytical tool for small-scale fisheries to identify what assets the fishers possess, what shocks and trends influence their daily lives and their livelihoods, which are the main structures and processes influencing and what are their livelihood strategies in such dynamic sector as small-scale fisheries are. This approach also allows to explore how livelihood outcomes could be influenced by adopting different livelihood strategies and how that would consequently affect the livelihood assets. Owing to this and its holistic view, the approach has been mainly used as a practical tool for poverty reduction programmes. However, to be able to identify all the elements, in particular, the livelihood assets, active participation or already existing data sets are necessary.

Adopted to the particular case of the mud crab fishery in South West Indian state of Karnataka, we found that the mud crab is perceived as a good source of income in this area, yet at present it is not recognised as a steady source of income due to the unpredictable fishery catches.
Fishers are constantly subjected to various stresses and trends such as seasonality and decreasing fish and crustacean stocks. However, due to the lack of significant information on catch effort, yield and recruitment, it is complicated to predict the livelihood outcomes in long-term. In addition, while respondents were aware of mud crab farming, the majority stated the lack of land and financial resources as the main barriers to consider this as income generating activity. Only a small minority expressed any interest in undertaking such activity. Compared to the body of literature stating that fishers adopt diversified livelihood strategies, we found that respondents in Uttara Kannada fully rely on fishing and fishing related activities.

Overall, we consider sustainable livelihood approach as a valuable tool in small-scale fisheries research both for preliminary studies and in depth-studies and the development of detailed support programmes. However, the effectiveness of the sustainable livelihood approach is linked to the availability of data on capital assets. In addition as assets evaluated can differ between studies, not only quantitative but also qualitative analysis is recommended for each case.

\section{Acknowledgments}

The authors are grateful to the fishers and middlemen from Uttara Kannada district for dedicating their time to participate in the survey and interviews. The authors are also thankful to Balachandra Hegde, Dr Mahabaleshwar R. Hegde, Dr Prakash Mesta and the Centre for Ecological Sciences Field Station in Kumta of the Indian Institute of Sciences for their help and fruitful discussions and translators Deepthi Hebbale, Prerana Shet, Pradnya Bandekar, Rajprasad Raikar and Shrikanth Naik. The study was approved by the Research Ethics Committee of the University of Plymouth. This study was funded by a $\mathrm{PhD}$ scholarship granted by the University of Plymouth to EA (PI LMT).

\section{Appendix A. Supplementary data}

Supplementary data to this article can be found online at https:// doi.org/10.1016/j.ocecoaman.2018.12.024.

\section{References}

Acemoglu, D., Robinson, J., 2008. The Role of Institutions in Growth and Development. Commission on Growth and Development. The World Bank, New York.

Adger, W.N., 2006. Vulnerability. Global Environ. Change 16 (3), 268-281. https://doi. org/10.1016/j.gloenvcha.2006.02.006.

Aldridge, A., Levine, K., 2001. Surveying the Social World. Principles and Practice in Survey Research. Open University Press, Philadelphia.

Allan, J.D., Abell, R., Hogan, Z., Revenga, C., Taylor, B.W., Welcomme, R.L., Winemiller, K., 2005. Overfishing of inland waters. Bioscience 55 (12), 1041-1051. https://doi. org/10.1641/0006-3568(2005)055[1041:OOIW]2.0.CO;2.

Allison, E.H., Ellis, F., 2001. The Livelihoods Approach and Management of Small-Scale Fisheries the livelihoods approach and management of small-scale fisheries. Mar. Pol. 25, 377-388. https://doi.org/10.1016/S0308-597X(01)00023-9.

Allison, E.H., Horemans, B., 2006. Putting the principles of the Sustainable Livelihoods Approach into fisheries development policy and practice. Mar. Pol. 30 (6), 757-766. https://doi.org/10.1016/j.marpol.2006.02.001.

Ashley, C., Carney, D., 1999. Sustainable Livelihoods: Lessons from Early Experience. Department for International Development, London, UK.

Aswani, S., Lemahieu, A., Sauer, W.H.H., 2018. Global trends of local ecological knowledge and future implications. PLoS One 13 (4), e0195440. https://doi.org/10.1371/ journal.pone.0195440.

Bakshi, A., 2008. Social inequality in land ownership in India: a study with particular reference to West Bengal. Soc. Sci. 36 (9), 95-116.

Basavakumar, K.V., Devendrappa, S., Srenivas, S.T., 2011. A study on profile of fishing community of a village in Karnataka. Karnataka J. Agric. Sci. 24 (5), 684-687.

Baulch, B., Hoddinott, J., 2000. Economic mobility and poverty dynamics in developing countries. J. Dev. Stud. 36 (6), 1-24. https://doi.org/10.1080/00220380008422652.

Bebbington, A., 1999. Capitals and capabilities: a framework for analyzing peasant viability, rural livelihoods and poverty. World Dev. 27 (12), 2021-2044. https://doi. org/10.1016/S0305-750X(99)00104-7.

Béné, C., 2009. Are Fishers poor or vulnerable? Assessing economic vulnerability in smallscale fishing communities. J. Dev. Stud. 45 (6), 911-933. https://doi.org/10.1080/ 00220380902807395.

Béné, C., 2015. The good, the bad and the Ugly: discourse, policy controversies and the role of science in the politics of shrimp farming. Dev. Policy Rev. 23 (5), 585-614. https://doi.org/10.1111/j.1467-7679.2005.00304.x. 
Berkes, F., Colding, J., Folke, C., 2010. Rediscovery of traditional ecological knowledge as adaptive management. Ecol. Appl. 10 (5), 1251-1262. https://doi.org/10.1890/ 1051-0761(2000)010[1251:ROTEKA]2.0.CO;2.

Besley, T., Leight, J., Pande, R., Rao, V., 2016. Long-run impacts of land regulation: evidence from tenancy reform in India. J. Dev. Econ. 118, 72-87.

Bhat, M., Nayak, V.N., Subash Chandran, D.M., Ramachandra, V.T., 2012. Impact of hydro-electric dams on fisheries in the Sharavati estuary of Uttara Kannada district, South-West India. In: Lake 2012: National Conference on Conservation and Management of Wetland Ecosystems.

Bhatta, R., Bhat, M., 1998. Impacts of aquaculture on the management of estuaries in India. Environ. Conserv. 25 (2), 109-121. https://doi.org/10.1017/ S0376892998000162.

Blythe, J., Flaherty, M., Murray, G., 2015. Vulnerability of coastal livelihoods to shrimp farming: insights from Mozambique. Ambio 44 (4), 275-284. https://doi.org/10. 1007/13280-014-0574-z.

Campbell, J., Whittingham, E., Townsley, P., 2006. Responding to coastal poverty: should we be doing things differently or doing different things? In: Hoanh, Chu Thai, Tuong, T.P., Gowing, J.W., Hardy, B. (Eds.), Environment and Livelihoods in Tropical Coastal Zones: Managing Agriculture, Fishery, Aquaculture Conflicts. International Rice Research Institute (IRRI); Colombo, Sri Lanka: International Water Management Institute (IWMI), Wallingford, UK: CABI; Los Banos, Philippines, pp. 309p.

Central Marine Fisheries Research Institute, 2010. Marine Fisheries Census 2010. Karnataka. Central Marine Fisheries Research Institute, Kochi.

Central Statistics Office, 2011. Manual on Fishery Statistics. CSO-MFS-2011. Government of India. Ministry of Statistics and Programme Implementation, Sansad Marg, New Delhi.

Chambers, R., Conway, G.R., 1992. Sustainable Rural Livelihoods: Practical Concepts for the 21st Century. Discussion Paper 296. Institute of Development Studies, Brighton, UK.

Chauhan, C.P.S., 2008. Education and caste in India. Asia Pac. J. Educ. 28 (3), 217-234. https://doi.org/10.1080/02188790802267332.

Das, M.K., Sharma, A.P., Sahu, S.K., Srivastava, P.K., Rej, A., 2013. Impacts and vulnerability of inland fisheries to climate change in the Ganga River system in India. Aquat. Ecosys. Health Manag. 16 (4), 415-424. https://doi.org/10.1080/14634988. 2013.851585.

Department of Animal Husbandry, Dairying and Fisheries, 2014. Handbook on Fisheries Statistics 2014. Government of India. Ministry of Agriculture and Farmers Welfare, New Delhi.

Department of Animal Husbandry, Dairying and Fisheries, 2015. Basic Animal Husbandry and Fisheries Statistics 2015. Government of India. Ministry of Agriculture and Farmers Welfare. Krishi Bhawan, New Delhi.

Department for International Development, 1999. Sustainable Livelihoods Guidance Sheets. Department for International Development, London.

Department of Fisheries, 2013. Mud Crab. Government of Western Australia. Department of Fisheries fact sheet No.28.

Department of Fisheries, 2018. Crab, Mud (Green and Brown). Western Australian Recreational Fishing Rules. Government of Western Australia Available at: http:// rules.fish.wa.gov.au/Species/Index/46, Accessed date: 7 November 2018.

ECFC, 2005. Empowerment of Coastal Fishing Communities for Livelihood Security (BGD/97/017). A Livelihood Analysis. The Technical Advisory Group of ECFC. GOB/ UNDP/FAO Project. October 2005.

Ellis, F., 2000. Rural Livelihoods and Diversity in Developing Countries. Oxford University Press, Oxford.

FAO, 2011. Review of the State of World Marine Fishery Resources. FAO Fisheries and Aquaculture Technical Paper No. 569, Rome, Italy.

FAO, 2015. FAO Yearbook. Fishery and Aquaculture Statistics 2015. (Rome, Italy).

FAO, 2018. FAO Yearbook. Fishery and Aquaculture Statistics 2016. (Rome, Italy).

Farrington, J., 2001. Sustainable Livelihoods, Rights and the New Architecture of Aid. Natural Resource Perspectives 69. Overseas Development Institute, London.

Ferdoushi, Z., Guo, Z.X., 2010. Economic analysis of traditional mud crab (Scylla sp.) fattening in Bangladesh. Marine. res. aqua. 1 (1), 5-13.

Fielder, D., Allan, G., 2004. Executive summary and recommendations. In: Allan, G., Fielder, D. (Eds.), Mud Crab Aquaculture in Australia and Southeast Asia. ACIAR Working Paper No. 54, 2004 of Conference, pp. 61-62.

Gatto, A.M., 1995. Sustainability: is it a well defined concept? Ecol. Appl. 5 (4), 1181-1183. https://doi.org/10.1056/NEJMoa1614362.

Goswami, C., Zade, V.S., 2015. Statistical analysis of fish production in India. Int. J. Innov. Res. Sci. Eng. Technol. 4 (2), 294-299.

Government of Karnataka, 2016. Fisheries Department. Introduction. Available at: http://www.karnataka.gov.in/fisheries/english/Pages/Introduction.aspx, Accessed date: 11 January 2018.

Gowing, J.W., Tuong, T.P., Hoanh, C.T., Khiem, N.T., 2006. Social and environmental impact of rapid change in coastal zone of Vietnam; and assessment of sustainability issues. In: Hoanh, Chu Thai, Tuong, T.P., Gowing, J.W., Hardy, B. (Eds.), Environment and Livelihoods in Tropical Coastal Zones: Managing Agriculture, Fishery, Aquaculture Conflicts. International Rice Research Institute (IRRI); Colombo, Sri Lanka: International Water Management Institute (IWMI), Wallingford, UK: CABI; Los Banos, Philippines, pp. 309p.

Hill, R.C., Bowen, P.A., 1997. Sustainable construction: principles and a framework for attainment. Constr. Manag. Econ. 15 (3), 223-239. https://doi.org/10.1080/ 014461997372971.

Hossain, M., Ut, T.T., Bose, M.L., 2006. Livelihood systems and dynamics of poverty in a coastal province of Vietnam. In: Hoanh, Chu Thai, Tuong, T.P., Gowing, J.W., Hardy, B. (Eds.), Environment and Livelihoods in Tropical Coastal Zones: Managing Agriculture, Fishery, Aquaculture Conflicts. International Rice Research Institute (IRRI); Colombo, Sri Lanka: International Water Management Institute (IWMI),
Wallingford, UK: CABI; Los Banos, Philippines, pp. 309p.

Jahan, H., Islam, M.S., 2016. Economic performance of live crab (Scylla serrata) business in the southwest coastal region of Bangladesh. Int. J. Fisher. Aquat. Stud. 4 (1) 453-457.

Jentoft, S., Chuenpagdee, R., 2015. Assessing governability of small-scale fisheries. In: Jentoft, S., Chuenpagdee, R. (Eds.), Interactive Governance for Small-fisheries. Global Reflections. Centre for Maritime Research MARE. Springer Int. Pub, Switzerland.

Johnson, D., 2015. Giant mud crab. In: Stewart, J., Hegarty, A., Young, C., Fowler, A.M., Craig, J. (Eds.), (2015). Status of Fisheries Resources in NSW 2013-14. NSW Department of Primary Industries, Mosman, pp. 391.

Jonah, F.E., Agbo, N.W., Agbeti, W., Adjei-Boateng, D., Shimba, M.J., 2015. The ecological effects of beach sand mining in Ghana using ghost crabs (Ocypode species) as biological indicators. Ocean Coast Manag. 112, 18-24. https://doi.org/10.1016/j. ocecoaman.2015.05.001.

Kathirvel, M., Srinivasagam, S., 1992. Resource and exploitation of mud crab Scylla serrata (Forskal) in India. In: Angell, C.A. (Ed.), Report of the Seminar on Mud Crab Culture and Trade, Bay of Bengal Programme, Madras. BOBP/REP/51, pp. 84-94.

Kébé, M., Muir, J., 2008. The sustainable livelihoods approach: new directions in West and Central African small-scale fisheries. In: Westlund, L., Holvoet, K., Kébé, M. (Eds.), Achieving Poverty Reduction through Responsible Fisheries. Lessons from West and Central Africa. FAO Fisheries and Aquaculture Technical Paper. No. 513, Rome, Italy.

Kébé, M., Jern, P., Collins, R., Kay, W., Kekula, E., 2009. A Livelihoods Analysis of Coasta Fisheries Communities in Liberia. FAO Fisheries and Aquaculture Circular, Rome, Italy No. 1043.

Kurien, J., 1996. Towards a New Agenda for Sustainable Small-scale Fisheries Development. SIFFS, Trivandrum.

Le Vay, L., 2001. Ecology and management of mud crab Scylla spp. Asian Fish Sci. 14, 101-111.

Lebata, Ma J.H.L., Le Vay, L., Primavera, J.H., Walton, M.E., Binas, J.N., 2007. Baseline assessment of fisheries for three species of mud crabs (Scylla spp.) in the mangroves of Ibajay, Aklan, Philippines. Bull. Mar. Sci. 80 (3), 891-904.

Lebata, Ma J.H.L., Le Vay, L., Walton, M.E., Binas, J.N., Quinitio, E.T., Rodriguez, E.M., Primavera, J.H., 2009. Evaluation of hatchery based enhancement of the mud crab, Scylla spp., fisheries in mangroves: comparison of species and release strategies. Mar. Freshw. Res. 60, 58-69.

Little, J.C., Hester, E.T., Carey, C.C., 2016. Assessing and enhancing environmental sustainability: a conceptual review. Environ. Sci. Technol. 50 (13), 6830-6845. https:// doi.org/10.1021/acs.est.6b00298.

Marichamy, R., Rajapackiam, S., 2001. The aquaculture of Scylla species in India'. Asian Fish Sci. 14, 231-238.

Marine Products Export Development Authority, 2018. Marine Products Exports. Available at: http://mpeda.gov.in/MPEDA/marine_products_exports.php\#, Accessed date: 2 November 2018.

McGinnis, M.D., Ostrom, E., 2014. Social-ecological system framework: initial changes and continuing challenges. Ecol. Soc. 19 (2), 30. https://doi.org/10.5751/ES-06387190230.

Mikulcak, F., Haider, J.L., Abson, D.J., Newig, J., Fischer, J., 2015. Applying a capitals approach to understand rural development traps: a case study from post-socialist Romania. Land Use Pol. 43, 248-258. https://doi.org/10.1016/j.landusepol.2014.10. 024.

Ministry of Social Justice and Empowerment, 2017. Scheduled Caste Welfare. Available at: http://socialjustice.nic.in/UserView/index?mid=19536, Accessed date: 18 July 2018.

Mirera, D.O., Ochiewo, J., Munyi, F., 2014. Social and economic implications of smallscale mud crab (Scylla serrata) aquaculture: the case of organised community groups. Aquacult. Int. 22 (4), 1499-1514. https://doi.org/10.1007/s10499-014-9762-x.

Morse, S., McNamara, N., Acholo, M., 2009. Sustainable Livelihood Approach: a Critical Analysis of Theory and Practice. Geographical Paper 189. The University of Reading.

Nayak, P.K., 2017. Fisher communities in transition: understanding change from a livelihood perspective in Chilika Lagoon, India. Maritime Stud. 16 (1). https://doi.org/ 10.1186/s40152-017-0067-3.

Neumann, B., Vafeidis, A.T., Zimmermann, J., Nicholls, R.J., 2015. Future coastal population growth and exposure to sea-level rise and coastal flooding - a global assessment. PLoS One 10 (3). https://doi.org/10.1371/journal.pone.0118571.

Ostrom, E., 2007. A diagnostic approach for going beyond panaceas. Proc. Natl. Acad. Sci. Unit. States Am. 104 (36), 15181-15187.

Páez-Osuna, F., 2001. The environmental impact of shrimp aquaculture: causes, effects, and mitigating alternatives. Environ. Manag. 28 (1), 131-140. https://doi.org/10. $1007 /$ s002670010212.

Prasad, P.N., Neelakantan, B., 1989. Maturity and breeding of the mud crab, Scylla serrata (Forskal)(Decapoda: Brachyura: portunidae). Proc. Indiana Acad. Sci. 98, 341-349.

Purvis, B., Mao, Y., Robinson, D., 2018. Three pillars of sustainability: in search of conceptual origins. Sustain. Sci. 5, 1-15. https://doi.org/10.1007/s11625-018-0627-5.

Putnam, R.D., 2001. Social capital: measurement and consequences. Isuma: Canadian J. Pol. Res. 2, 41-51.

Quinitio, E.T., Parado-Estepa, F.D., Rodriguez, E., 2002. Seed production of mud crab Scylla spp. Aquaculture Depa VII (3), 29-31.

Rawal, V., 2008. Ownership holdings of land in rural India: putting the record straight. Econ. Pol. Wkly. 43 (10), 43-47. Available at: http://www.jstor.org/stable/ 40277229.

Ruscoe, I.M., Shelley, C.C., Williams, G.R., 2004. The combined effects of temperature and salinity on growth and survival of juvenile mud crabs (Scylla serrata Forsskål). Aquaculture 238 (1-4), 239-247. https://doi.org/10.1016/j.aquaculture.2004.05. 030. 
Sathiadhas, R., Najmudeen, T.M., 2004. Economic evaluation of mud crab farming under different production systems in India. Aquacult. Econ. Manag. 8 (1-2), 99-110.

Saunders, B., Sim, J., Kingstone, T., Baker, S., Waterfield, J., Bartlam, B., Burroughs, H., Jinks, C., 2018. Saturation in qualitative research: exploring its conceptualization and operationalization. Qual. Quantity 52 (4), 1893-1907. https://doi.org/10.1007/ s11135-017-0574-8.

Scoones, I., 1998. Sustainable Rural Livelihoods: a Framework for Analysis. IDS Working Paper. No.72. Brighton: IDS.

Sen, A., 1997. Editorial: human capital and human capability. World Dev. 25 (12), 1959-1961. https://doi.org/10.1016/S0305-750X(97)10014-6.

Sen, S., Homechaudhuri, S., 2017. Population characteristics and trends in artisanal fishery of Scylla serrata (Forsskål, 1775) in Indian Sundarban: implications on future managements. Ocean Coast Manag. 143, 105-114. https://doi.org/10.1016/j. ocecoaman.2016.08.021.

Sheeba, S., 2009. Biotic environment and sand mining - a case study from Ithikkara river, south west coast of India. Jr. Ind. Poll. Contr. 25 (2), 133-138.

Soini, K., Birkeland, I., 2014. Exploring the scientific discourse on cultural sustainability. Geoforum 51, 213-223. https://doi.org/10.1016/j.geoforum.2013.12.001.

Son, H.H., 2012. On Measuring Human Capital: a Case Study of Viet Nam. ADB Economics Working Paper Series No. 311. Asian Development Bank, Philippines.

Spangenberg, J.H., 2002. Institutional sustainability indicators: an analysis of the institutions in agenda 21 and a draft set of indicators for monitoring their effectivity. Sustain. Dev. 10, 103-115. May 2001. https://doi.org/10.1002/sd.184.

Subash Chandran, M.D., Mesta, P., Boominathan, M., Rao, G.R., Ramachandra, T.V.,
2012. Aghanashini estuary in Kumta taluk, Uttara Kannada - biological heritage site. ENVIS Technical Report: 35.

Sulochanan, B., 2013. Mangrove Ecosystem and its Impact on Fisheries. Available at: http://eprints.cmfri.org.in/9873/1/Bindu_10.pdf, Accessed date: 15 February 2018.

Thampi Samraj, Y.C., Mandal, A., Kumaran, G., Sethuramalingam, A., Srinivasan, P.,

Kumar, J., 2015. Status of mud crab industry in India. In: Quinitio, E.T., ParadoEstepa, F.D., Thampi Sam Raj, Y.C., Mandal, A. (Eds.), Proceedings of the International Seminar-workshop on Mud Crab Aquaculture and Fisheries

Management, 10-12 April 2013, Tamil Nadu, India. Rajiv Gandhi Centre for Aquaculture (MPEDA), Tamil Nadu, India, pp. 17-26.

Vincenzi, S.L., Possan, E., Andrade, D. F. de, Pituco, M.M., Santos, T. de O., Jasse, E.P., 2018. Assessment of environmental sustainability perception through item response theory: a case study in Brazil. J. Clean. Prod. 170, 1369-1386. https://doi.org/10. 1016/j.jclepro.2017.09.217.

Walton, M.E., Le Vay, L., Lebata, J.H., Binas, J., Primavera, J.H., 2006. Seasonal abundance, distribution and recruitment of mud crabs (Scylla spp.) in replanted mangroves. Estuar. Coast Shelf Sci. 66, 493-500.

Woolcock, M., Narayan, D., 2000. Social capital: implications for development theory, and policy. World Bank Res. Obs. 15 (2), 225-249. https://doi.org/10.1093/wbro/ 15.2.225.

Woolcock, M., 1998. Social capital and economic development: toward a theoretical synthesis and policy framework. Theor. Soc. 27, 151-208.

World Bank, 2012. Inclusive Green Growth: the Pathway to Sustainable Development. (Washington, DC). 